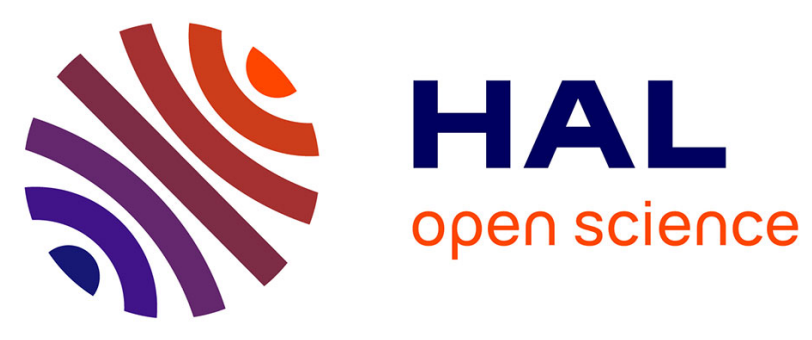

\title{
Crystal structure, phase transitions, optical and electrical properties in a new Cu-halide organic-inorganic hybrid
}

I. Ben Hadj Sadok, F. Hajlaoui, K. Karoui, Nathalie Audebrand, Thierry Roisnel, N. Zouari

\section{To cite this version:}

I. Ben Hadj Sadok, F. Hajlaoui, K. Karoui, Nathalie Audebrand, Thierry Roisnel, et al.. Crystal structure, phase transitions, optical and electrical properties in a new $\mathrm{Cu}$-halide organic-inorganic hybrid. Journal of Molecular Structure, 2019, 1186, pp.118-126. 10.1016/j.molstruc.2019.03.025 . hal-02122171

\section{HAL Id: hal-02122171 \\ https://hal-univ-rennes1.archives-ouvertes.fr/hal-02122171}

Submitted on 2 Jul 2019

HAL is a multi-disciplinary open access archive for the deposit and dissemination of scientific research documents, whether they are published or not. The documents may come from teaching and research institutions in France or abroad, or from public or private research centers.
L'archive ouverte pluridisciplinaire HAL, est destinée au dépôt et à la diffusion de documents scientifiques de niveau recherche, publiés ou non, émanant des établissements d'enseignement et de recherche français ou étrangers, des laboratoires publics ou privés. 


\title{
Crystal structure, phase transitions, optical and electrical properties in a new Cu-halide organic-inorganic hybrid
}

Ines Ben Hadj Sadok ${ }^{\mathrm{a}}$, Fadhel Hajlaoui*a ${ }^{\mathrm{a}}$, Karim Karoui ${ }^{\mathrm{b}}$, Nathalie Audebrand ${ }^{\mathrm{c}}$, Thierry Roisnel ${ }^{\mathrm{c}}$, Nabil Zouari ${ }^{\mathrm{a}}$

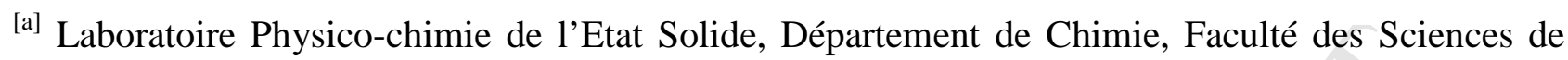
Sfax, B.P. 1171, 3000 Sfax, Université de Sfax, Tunisia.

${ }^{[b]}$ Laboratoire des caractérisations spectroscopiques et optique des matériaux, Faculté des Sciences de Sfax-3000, Sfax, Tunisia.

${ }^{[c]}$ Univ. Rennes, CNRS, ISCR (Institut des Sciences Chimiques de Rennes) - UMR 6226, F-35000 Rennes, France

\author{
AUTHOR INFORMATION \\ * Corresponding author: Fadhel Hajlaoui. \\ * Email address: fadhelh83@yahoo.fr (F. Hajlaoui).
}

\begin{abstract}
Single crystals of a new hybrid metal halide $\left[\mathrm{C}_{7} \mathrm{H}_{16} \mathrm{~N}_{2}\right]\left[\mathrm{CuCl}_{4}\right]$ were grown by hydrothermal technique and characterized by single-crystal X-ray diffraction, IR and Raman spectroscopy, optical absorption, differential scanning calorimetry and dielectric measurements. The compound $\left[\mathrm{C}_{7} \mathrm{H}_{16} \mathrm{~N}_{2}\right]\left[\mathrm{CuCl}_{4}\right]$ crystallizes in the monoclinic space group $P 2_{1} / c$ at room temperature. In the molecular structure, the tetrachlorocuprate anions are linked to the organic cations through $\mathrm{N}-\mathrm{H}^{\cdots}{ }^{\cdots} \mathrm{Cl}$ hydrogen bonds. The Raman and IR analyses confirm the presence of the organic groups and the anionic entities. UV-Visible absorption spectrum revealed the energy of the optical band gap. The DSC measurements indicated that $\left[\mathrm{C}_{7} \mathrm{H}_{16} \mathrm{~N}_{2}\right]\left[\mathrm{CuCl}_{4}\right]$ underwent two sequential phase transitions at around 288 and $388 \mathrm{~K}$. The temperature dependence of the electrical conductivity confirmed the phase transitions that were well detected with differential scanning calorimetry. The analysis of Nyquist plots revealed the contribution of the bulk mechanism and the grain boundaries.
\end{abstract}

Keywords: Crystal structure, Hybrid metal halide, Optical band gap, Phase transitions, Electrical properties, Conduction mechanism. 


\section{Introduction}

In the past decade, a great attention has been devoted to the family of hybrid metal halides thanks to their potential applications in the fields of magnetism [1-3], ferroelectrics and electrical properties [4-8], optoelectronics and memory devices [9-11]. These types of materials have also received much attention owing their interesting molecular shapes. Moreover, the hybrid compounds have stimulated modern-day materials science research due to their innumerable characteristics such as flexibility, specific structural architectures and potential phase transition materials [12-13]. Actually, inorganic-organic phase transition materials with formula $\mathrm{AMX}_{4}$ have been synthesized, in which $\mathrm{M}$ is a metal cation that coordinated by four $(\mathrm{X})$ anions to form an $\mathrm{AX}_{4}$ tetrahedron, and $\mathrm{A}$ is a organic cation. Especially, metal-halide compounds including 2-methylpiperazine, 1,4-diazabicyclo [2.2.2] octane and quinuclidine have made further progress [14-20]. For example, [quinuclidinium][ReO $\left.\mathrm{Re}_{4}\right][16-17] ;\left(\mathrm{H}_{2} \mathrm{dabco}-\mathrm{C}_{2} \mathrm{H}_{5}\right)\left[\mathrm{MCl}_{4}\right]$ [20] and $\left(\mathrm{H}_{2} \mathrm{dabco}-\mathrm{CH}_{2}-\mathrm{Cl}\right)\left[\mathrm{MCl}_{4}\right]$ [19] contain an independent organic cations and a discrete $\left[\mathrm{MX}_{4}\right]^{\mathrm{n}-}(\mathrm{M}=\mathrm{Co}, \mathrm{Zn})$ anions. Quinuclidinium perrhenate (I) compound, exhibits ferroelectricity above room temperature, polarization rotation and undergoes a phase transition to a plastic crystal phase at a higher temperature [17]. Eventually, these hybrid materials containing quinuclidine (1-azabicyclo[2.2.2] octane) or its derivatives as templating agents has led to the preparation of some materials with interesting physical properties such as a switchable polarity, ferroelectricity, piezoelectricity, second-harmonic generation (SHG), luminescence and optical activity [16, 21-22]. Herein, 3-aminoquinuclidine as the derivative of dabco, was protonated and combined with metal halides, forming a new hybrid compound $\left[\mathrm{C}_{7} \mathrm{H}_{16} \mathrm{~N}_{2}\right]\left[\mathrm{CuCl}_{4}\right]$. In this paper we present the structural characterization, optical studies, differential scanning calorimetric analysis, electric and dielectric measurements as a function of temperature.

\section{Experimental section}

\subsection{Materials}

Copper(II) chloride $\left(\mathrm{CuCl}_{2}\right)$, hydrochloric acid ( $\left.\mathrm{HCl} ; 37 \%\right)$, 3-aminoquinuclidine dihydrochloride were purchased from Sigma-Aldrich and used without further purification.

\subsection{Synthesis}

The synthesis of 3-aminoquinuclidinediium tetrachlorocuprate(II) complex was carried out in home-built Teflon-lined stainless steel pressure bombs of $120 \mathrm{~mL}$ maximum capacity. $1 \mathrm{mmol}$ of $\mathrm{CuCl}_{2}$ and $2 \mathrm{mmol}$ of 3-aminoquinuclidine dihydrochloride were dissolved together in $20 \mathrm{~mL}$ of deionized water and hydrochloric acid. The mixture was placed in a Teflon-lined autoclave that was then sealed and heated to $120^{\circ} \mathrm{C}$ for 2 days. It was then allowed to cool to room temperature in a cold water bath. Autoclaves were opened in air, and products were recovered through filtration. Orange stick-shaped crystals with suitable dimensions for crystallographic study were recovered. 
The crystals were washed several times with distilled water and dried in open air. Reaction yields ranged between $60-79 \%$ based on $\mathrm{Cu}$.

\subsection{Single-crystal data collection and structure determination}

Suitable crystals were mounted on an APEX II AXS-Bruker area detector 4-circles diffractometer. Intensity data sets were collected using Mo K $\alpha$ radiation $(\lambda=0.71073 \AA)$ through the Bruker AXS APEX2 Software Suite [23]. Frame integration and data reduction were carried out with the program SAINT [24]. The program SADABS [25] was then employed for multiscan-type absorption corrections. The crystal structure was solved in the monoclinic symmetry, space group $P 2_{1} / c$, according to the automated search for space group available in WinGX [26]. Copper and chloride atoms were located using the direct methods with the program SIR-2014 [27]. C and N atoms from the amine were found from successive difference Fourier calculations using SHELXL2014 [28]. Their positions were validated from geometrical considerations as well as from the examination of possible hydrogen bonds. $\mathrm{H}$ atoms were positioned geometrically and allowed to ride on their parent atoms, with $\mathrm{C}-\mathrm{H}=0.97 \AA$ and $\mathrm{N}-\mathrm{H}=0.89 \AA$. When the nitrogen is the protonated tertiary one, $\mathrm{N}(2)$ and $\mathrm{N}(4)$, the distance is fixed to $0.98 \AA$. Structure drawings have been made with Olex2 [29] program. Crystallographic data are given in Table 1.

\subsection{Spectroscopies studies}

The Raman spectra were excited by the $514.5 \mathrm{~nm}$ wavelength radiation of an $\mathrm{Ar} / \mathrm{Kr}$ laser, and collected with a T64000 Raman spectrometer in the $180-3500 \mathrm{~cm}^{-1}$ range. The spectrum was collected in all polarizations, but only the obtained in the $\mathrm{Z}(\mathrm{XX}) \mathrm{Z}$ polarization is presented with regard to their best signal-to-noise ratio.

IR absorption spectrum of the crystallized powders in $\mathrm{KBr}$ was recorded on a Perkin- Elmer FT-IR 1000 spectrometer in the $400-4000 \mathrm{~cm}^{-1}$ range.

Optical properties are measured at room temperature using a Shimadzu-type 3101PC UV spectrophotometer that has a dual-beam monochromator, covers a spectrum from $200 \mathrm{~nm}$ to 2400 nm and uses two sources: (i) Xenon lamp for the UV-Visible domain, (ii) Halogen lamp for the infrared range. This technique makes it possible to determine the absorbance (A) and the reflectance (R). The optical absorption spectrum of the $\left[\mathrm{C}_{7} \mathrm{H}_{16} \mathrm{~N}_{2}\right]\left[\mathrm{CuCl}_{4}\right]$ compound was recorded at room temperature in powder used in the form of films.

\subsection{Thermal measurements}

TGA measurements were performed on raw powders with a TGA 'SETSYS Evolution' under an $\mathrm{N}_{2}$ atmosphere of $\left[\mathrm{C}_{7} \mathrm{H}_{16} \mathrm{~N}_{2}\right]\left[\mathrm{CuCl}_{4}\right]$. The thermogram was collected on $12.5 \mathrm{mg}$ sample in the RT$873 \mathrm{~K}$ range (heating rate of $5^{\circ} \mathrm{C} / \mathrm{min}$ ). 
DSC measurements were recorded on raw powders with NETZCSCH DSC 200 F3 instrument (Pt crucibles, $\mathrm{Al}_{2} \mathrm{O}_{3}$ as a reference) under nitrogen atmosphere. The thermograms were collected on $8 \mathrm{mg}$ sample in the temperature range from 258 to $423 \mathrm{~K}$ with heating and cooling rate of $5{ }^{\circ} \mathrm{C} / \mathrm{min}$.

\subsection{Impedance spectroscopy}

The electrical measurements of the real and imaginary components of the impedance parameters ( $Z^{\prime}$ and Z") were measured on pellet disks of about $8 \mathrm{~mm}$ in diameter and $1.2 \mathrm{~mm}$ in thickness in the frequency range of $1-10^{6} \mathrm{~Hz}$, with the SOLARTRON SI 1260 impedance coupled to a dielectric interface 1296 in the temperature range of $273-430 \mathrm{~K}$.

\section{Results and discussion}

\subsection{Crystal Structure}

The structure of $\left[\mathrm{C}_{7} \mathrm{H}_{16} \mathrm{~N}_{2}\right]\left[\mathrm{CuCl}_{4}\right]$ compound was determined by $\mathrm{X}$-ray diffraction analysis. At room temperature, data were consistent with the monoclinic space group $P 2_{1} / c$, with unit cell parameters $a=21.4852(1) \AA, b=7.3367(3) \AA, c=17.1508(8) \AA, \beta=105.865(2)^{\circ}$ and $Z=4$. The asymmetric unit consists of discrete $\left[\mathrm{CuCl}_{4}\right]^{2-}$ anions and two symmetrically independent $\left[\mathrm{C}_{7} \mathrm{H}_{16} \mathrm{~N}_{2}\right]^{2+}$ cations (Figure 1). The $\left[\mathrm{CuCl}_{4}\right]^{2-}$ complexes anions adopt intermediate geometry between square-planar and regular tetrahedra with $\mathrm{Cu}-\mathrm{Cl}$ bond distances ranging from 2.2123(9) $\AA$ to 2.2708(9) $\AA$ in $\left[\mathrm{Cu}_{1} \mathrm{Cl}_{4}\right]^{2-}$ and from 2.2211(1) to 2.2654(8) $\AA$ in $\left[\mathrm{Cu}_{2} \mathrm{Cl}_{4}\right]^{2-}$. Meanwhile, the $\mathrm{Cl}-\mathrm{Cu}-\mathrm{Cl}$ bond angles range between 96.58 (3) and 135.39 (4) ${ }^{\circ}$ for $\left[\mathrm{Cu}_{1} \mathrm{Cl}_{4}\right]^{2-}$ and between 98.07 (3) and $130.34(4)^{\circ}$ for $\left[\mathrm{Cu}_{2} \mathrm{Cl}_{4}\right]^{2-}$, which are seriously deviated from the ideal values of $109.5^{\circ}$ (Table 2). A description of the distortion from tetrahedral geometry has been evaluated by the Muetterties and Guggenberger method $[\Delta D=0$ for a regular tetrahedron and $\Delta D=100$ for a squareplanar $\left(D_{4 \mathrm{~h}}\right)$ geometry]. The calculated $\Delta D(\%)$ parameters for $\left[\mathrm{Cu}_{1} \mathrm{Cl}_{4}\right]^{2-}$ and $\left[\mathrm{Cu}_{2} \mathrm{Cl}_{4}\right]^{2-}$ are $26.8 \%$ and $27.5 \%$, respectively. Therefore, the coordination geometry around the $\mathrm{Cu}{ }^{\mathrm{II}}$ ion can be described as a distorted tetrahedron. The geometrical features of $\mathrm{CuCl}_{4}$ entities agree well with those reported for other $\mathrm{Cu}$ (II) salts containing isolated tetrahedra $[31,32]$. In the case of the $\left[\mathrm{C}_{7} \mathrm{H}_{16} \mathrm{~N}_{2}\right]^{2+}$ cation, the selected bond lengths and angles fall within the normal ranges. Indeed, the N-C, C-C distances and the N-C-C, C-N-C, C-C-C angles are comparable with those observed in other similar hybrid metal-halides with the same organic cation [33, 34]. The crystal structure is stabilized by intermolecular hydrogen-bonding interactions leading to layers that are parallel to $\mathrm{b}$ and $\mathrm{c}$ axes (Figure 2). Within the intermolecular bonds, the distances of $\mathrm{N} \cdots \mathrm{Cl}$ interactions fall in the range of 3.227(3) - 3.448(3) $\AA$, and the angles range from 130 to $157^{\circ}$. The hydrogen bond parameters are given in Table 3 . The hydrogen bonds connect the cations and anions play a significant role in the formation of three-dimensional frameworks and stabilizing the supramolecular structure. 


\subsection{Vibrational frequencies}

Raman and IR complementary techniques are used to identify the presence of all molecular groups for the synthesized compound. These spectra are recorded in Figure 3 (a) and (b). The Raman spectrum shows three frequency regions: the first under $350 \mathrm{~cm}^{-1}$ corresponding to the $\mathrm{Cu}-\mathrm{Cl}$ vibration modes and indicates the presence of the $\mathrm{CuCl}_{4}{ }^{2-}$ anion, the second region between 383 and $1570 \mathrm{~cm}^{-1}$ corresponds to the $\mathrm{NC}_{4}, \mathrm{CH}_{2}, \mathrm{NH}_{3}$ and $\mathrm{C}-\mathrm{N}-\mathrm{H}$ vibrations modes, the third region above the $2900 \mathrm{~cm}^{-1}$ indicate the $\mathrm{C}-\mathrm{H}$ stretching vibration. All vibrations modes of the organic cation above $383 \mathrm{~cm}^{-1}$ appears with a small difference in frequency in the IR spectrum. This result confirms the presence of the inorganic and organic entities proved by the X-ray diffraction analysis. Table S1 (See Supporting Information) lists the corresponding calculated modes of such observed peaks.

\subsection{Optical energy gap analysis of $\left[\mathrm{C}_{7} \mathrm{H}_{16} \mathrm{~N}_{2}\right]\left[\mathrm{CuCl}_{4}\right]$}

UV-visible optical absorption spectrum of the $\left[\mathrm{C}_{7} \mathrm{H}_{16} \mathrm{~N}_{2}\right]\left[\mathrm{CuCl}_{4}\right]$ shows the presence of three bands (Figure 4). The strong band noticed around $287 \mathrm{~nm}$ is ascribed to the excitation of an electron from the valence band to the conduction band in the $\left[\mathrm{CuCl}_{4}\right]^{2-}$ tetrahedron, indicating the gap of this material. The valence and conduction bands are represented by the orbital (3p) of copper and (3p) of $\mathrm{Cl}$, respectively [35]. Absorption band at $400 \mathrm{~nm}$ may be due to excitonic absorption in the band gap. The band observed at $683 \mathrm{~nm}$ corresponds to an emission band in the visible red spectral range. Based on the Tauc's expression [36], we have deducted the gap energy for the direct and indirect transition by the extrapolation of the linear part of the curve (Figure 5) with the energy axis. The direct and indirect gap energy values are $4.61 \mathrm{eV}$ and $3.52 \mathrm{eV}$, respectively.

It is trustworthy to mention that the discreet variation in the angular distortions correlates well with the materials band gap, as revealed by UV-vis spectroscopy [37-40]. The determination of the band gap energy is realized by the distortion of the inorganic parts. The supporting distortion and shrinkage of $\left[\mathrm{CuCl}_{4}\right]^{2-}$ coordination lead to a considerable band gap tightening, which is of fundamental significance for the optoelectronics applications. Furthermore, the length and shape of the organic part may have an impact on the structure and band gap behaviors, which is the new vision for the organic-inorganic-like materials. Essentially, the band gap of $\left[\mathrm{C}_{7} \mathrm{H}_{16} \mathrm{~N}_{2}\right]\left[\mathrm{CuCl}_{4}\right]$ is smaller than the calculated values of the direct band gaps found in the three compounds $\left[\left(\mathrm{CH}_{3}\right)_{3} \mathrm{NH}\right]\left[\mathrm{CdCl}_{3}\right](5.41$ and $5.30 \mathrm{eV})$ [40]; $\left[\mathrm{N}\left(\mathrm{CH}_{3}\right)_{4}\right]_{2}\left[\mathrm{CoCl}_{4}\right](4.65$ and $4.66 \mathrm{eV})$ [41] and $\left[\mathrm{N}\left(\mathrm{CH}_{3}\right)_{4}\right]_{2}\left[\mathrm{MnCl}_{4}\right]$ (5.35 and $5.38 \mathrm{eV}$ ) [41], respectively. Hence, the calculated value of the title compound may be categorized as semiconductor material.

\subsection{Thermal behavior}

TGA and DSC measurements were carried out to highlight the phase transitions and the thermal stability of the compound. The TG thermogram shows that the compound seems to be stable up to 
$453 \mathrm{~K}$. Above this temperature, a gradual weight loss appears at $460 \mathrm{~K}$ and that is considered like a limit of thermal stability of the compound (Figure 6). The transformation occurs in the temperature range 463-623K. The weight loss can be attributed to the decomposition of the amine group together with the chloride is removed to support the charge neutrality and corresponds to the formation of $\mathrm{CuCl}_{2}$ (observed weight loss, 60.51\%, theoretical, 59.71\%). A similar decomposition has been observed in other hybrid-halide compounds [5, 20, 32].

DSC thermograms were recorded on heating and cooling (Figure 7) in the temperature range between 258 and $423 \mathrm{~K}$. This study shows two sequential phase transitions on heating, the first of which is weak at $T_{1}=288 \mathrm{~K}$ and the second is intense at $\mathrm{T}_{2}=388 \mathrm{~K}$.

\subsection{Electrical properties}

\subsubsection{Impedance spectroscopy}

The illustration of the impedance data in the complex plane permits the determination of the various contributions in the material, as the grain, grain boundary, and electrode contribution. Figure 8 shows the Nyquist diagram measured at several temperatures. All these plots are characterized by two semi-circles and a tail at lower frequencies, revealing the existence of three contributions. Indeed, the first one detected at high frequency describes the grain contribution, while the second is due to grain boundary one and the third at low frequency is due to the electrode response. The radius of the arc corresponding to the bulk resistance of the sample decreases with the increase of temperature, showing an activated thermal conduction mechanism. These diagrams are modeled with an equivalent circuit using the Z-VIEW software $\left(\left(\mathrm{R}_{\mathrm{g}} / / \mathrm{C}\right)+\left(\mathrm{R}_{\mathrm{jg}} / / \mathrm{CPE}\right)+\mathrm{CPE}\right)$ where $\mathrm{R}_{\mathrm{g}}$ and $\mathrm{R}_{\mathrm{jg}}$ the resistance of grains and grain boundaries, respectively, $\mathrm{C}$ and CPE the capacitance and capacity of the fractal interface, respectively. In order to substantiate the choice of equivalent circuit, we simulate the variation of $\mathrm{Z}^{\prime}$ and $\mathrm{Z}^{\prime \prime}$ as a function of frequency with the obtained parameters by the Z-VIEW software. The good matching between the experimental and calculated curves highlights that this equivalent circuit is well described the electrical behavior of this compound (Figure 9). The conductivity $\sigma_{\mathrm{g}}$ is obtained from $(\mathrm{Rp})$ by means of the relation:

$$
\sigma_{g}=\frac{\mathrm{e}}{\mathrm{R} * \mathrm{~S}}
$$

where $\mathrm{R}_{\mathrm{g}}$ is the bulk resistance obtained from the intercept of the semicircular arcs, observed at higher frequency, on the real axis (Z') and (e/S) represents the sample geometrical ratio. The temperature dependence of the conductivity $\sigma_{\mathrm{g}}$ is showed in Figure 10. This variation is described by three slope changes, thus confirming the two-phase transitions observed in the calorimetric study and revealing the existence of four phases, of which three are described by the Arrhenius law. The change of slope at $\mathrm{T}=373 \mathrm{~K}$ is due to the evaporation of water in this material; which indicates that phase II between $300 \mathrm{~K}$ and $373 \mathrm{~K}$ is not described by the Arrhenius law. This 
material shows the hygroscopic character that influenced the variation of the conductivity. The calculated activation energy from linear fits to the data points of the described phases by the Arrhenius law are: $\mathrm{E}_{\mathrm{I}}=0.08 \mathrm{eV}, \mathrm{E}_{\mathrm{III}}=0.15 \mathrm{eV}$ and $\mathrm{E}_{\mathrm{IV}}=1.45 \mathrm{eV}$.

\subsubsection{Modulus study}

Figure 11 presents two peaks of M" versus frequency. While the most intense peaks are associated with the grain effects (these peaks shift toward higher angular frequencies with the increase in temperature), the others are associated with the effects of grain boundaries, which confirms the observed result in the impedance spectra. These spectra of modulus M" are fitted with the approximate frequency representation of the Kohlrausch-Williams-Watts (KWW) function, proposed by Bergman [42]:

$$
M^{\prime \prime}=\frac{M_{1 \text { max }}^{\prime \prime}}{\left(1-\beta_{1}\right)+\frac{\beta_{1}}{1+\beta_{1}}\left[\beta_{1}\left(\frac{\omega_{\text {max }}}{\omega}\right)+\left(\frac{\omega}{\omega_{\text {max }}}\right)^{\beta_{1}}\right]}+\frac{M_{2}^{\prime \prime}{ }_{\text {max }}^{\prime}}{\left(1-\beta_{2}\right)+\frac{\beta_{2}}{1+\beta_{2}}\left[\beta_{2}\left(\frac{\omega_{2 \text { max }}}{\omega}\right)+\left(\frac{\omega}{\omega_{\text {max }}}\right)^{\beta_{2}}\right]}
$$

where M" max and $\omega_{\max }$ are the modulus maximum and the frequency at which M" maximum, respectively.

The fitted value of $\omega_{\max }$ allows to deduce the $f_{\max }$, which is plotted in the Figure 12. This variation is given by the relation: $f_{\max }=\mathrm{A} \exp (-\mathrm{Ea} /(\mathrm{kT}))$; where $\mathrm{A}$ is the pre-exponential factor, $\mathrm{E}_{\mathrm{a}}$ is the activation energy and $\mathrm{k}$ is the Boltzmann's constant. The variation of $f_{\max }$ confirms the temperature transitions discovered in the calorimetric study, in which a modification of the slope curve is observed near each transition. Phases I, III and IV are well described by the Arrhenius relation. The determined activation energy in each phase is: $\mathrm{E}_{\mathrm{I}}=0.48 \mathrm{eV}, \mathrm{E}_{\mathrm{III}}=0.27 \mathrm{eV}$ and $\mathrm{E}_{\mathrm{IV}}=2.08 \mathrm{eV}$.

\subsubsection{AC-conductivity and conduction mechanism}

As shown in Figure 13, AC conductivity versus frequency at various temperatures of the sample under investigation displays independent-dc plateau at lower frequencies and frequency dependentac dispersion region at higher frequencies, which exhibits the distinctive behavior of the compound conductivity. This dependence of conductivity on frequency or so-called universal dynamic response of conductivity is related by a simple expression given by Jonscher's power law: [43, 44].

$$
\sigma_{A C}=\sigma_{d c}+A \omega
$$


where $\sigma_{\mathrm{AC}}$ is the ac conductivity, $\sigma_{\mathrm{dc}}$ is the direct current conductivity, $\mathrm{A}$ is a pre-exponential constant, $\omega=2$ pf is the angular frequency and S lying between 0 and 1 is the power law exponent that implies the degree of interaction between the charge carriers and the lattice [45, 46]. The spectra of Ac conductivity as a function of frequency are thermally activated, increasing with the increase in temperature (Figure 13). The simulate Ac conductivity spectra based on the Jonscher's power law allows the determination of the direct current conductivity, pre-exponential constant $\mathrm{A}$ and the exponent $\mathrm{S}$. The variation of the $\sigma_{\mathrm{dc}}$ conductivity as a function of temperature (Figure 14) show Arrhenius-type behavior in phases I, III and IV, which reveals a change of the curve slope at the two transitions phases observed in the calorimetric study and asserts the obtained result in the variation of $\sigma_{\mathrm{g}}$. The activation energy calculated from linear fit to the data points is $\mathrm{E}_{\mathrm{I}}=0.15 \mathrm{eV}, \mathrm{E}_{\mathrm{III}}=0.35 \mathrm{eV}$ and $\mathrm{E}_{\mathrm{IV}}=1.24 \mathrm{eV}$.

The values of the activation energies obtained from the analysis of equivalent circuit, modulus, and conductivity data are diverse. These results indicate that the transport is not through ion hopping mechanism in the investigated sample [47]. In fact, the conduction mechanism of our sample is linked by the variation of exponent $S$ as a function of temperature. Different models have been considered in the literature based on two distinct processes: classical hopping over a barrier and quantum-mechanical tunneling, or combination of the two. These models are interconnected with the temperature variation (Figure 15) and a slope change near each transition specifies all phase transitions. According to this variation, the NSPT model can properly describe phases I and II, in which the values of $(S)$ increase with the increase in temperature $[48,49]$. In the overlapping large polaron tunneling OLPT model, the exponent $\mathrm{S}$ depends on both temperature and frequencies. Indeed, it decreases with the increase in temperature to a minimum value, and then augments when the temperature rises. This behavior can describe phase IV [50].

\section{Conclusion}

In summary, we successfully synthesized a low-dimensional hybrid copper halide, namely $\left[\mathrm{C}_{7} \mathrm{H}_{16} \mathrm{~N}_{2}\right]\left[\mathrm{CuCl}_{4}\right]$, by a facile hydrothermal method, which exhibits two sequential phase transitions at about 288 and $388 \mathrm{~K}$, being confirmed by the DSC measurements together with dielectric anomalies. The compound crystallizes in the monoclinic system, space group $\mathrm{P} 2{ }_{1} / \mathrm{c}$ with $\mathrm{Z}=4$. The cationic $\left[\mathrm{C}_{7} \mathrm{H}_{16} \mathrm{~N}_{2}\right]^{2+}$ and anionic $\left[\mathrm{CuCl}_{4}\right]^{2-}$ entities are linked with each other by $\mathrm{N}-\mathrm{H} \cdots \mathrm{Cl}$ hydrogen bonding to generate an interesting 3D supramolecular framework. The optical properties at the absorption edge of $\left[\mathrm{C}_{7} \mathrm{H}_{16} \mathrm{~N}_{2}\right]\left[\mathrm{CuCl}_{4}\right]$ showed three distinct peaks at 287, 400 and $683 \mathrm{~nm}$, respectively. The value of the gap energy $\left(\mathrm{E}_{\mathrm{g}}\right)$ is $4.61 \mathrm{eV}$. The equivalent circuit was determined and the impedance studies have clearly revealed the contributions of grain and grain boundary to the conduction process in the compound. 


\section{Appendix}

Supplementary crystallographic data for this article in CIF format are available as Electronic Supplementary Publication from Cambridge Crystallographic Data Centre (CCDC 1553896). This data can be obtained free of charge via http://www.ccdc.cam.ac.uk/conts/retrieving.html, or from the Cambridge Crystallographic Data Centre, 12 Union Road, Cambridge CB2 1EZ, UK (Fax: (international): +44 1223/336033; e-mail: deposit@ccdc.cam.ac.uk).

\section{Acknowledgments}

The authors would gratefully acknowledge the help of the Ministry of Higher Education and Scientific Research, Tunisia.

\section{Conflicts of interest}

There are no conflicts to declare.

\section{References}

[1] A. O. Polyakov, A. H. Arkenbout, J. Baas, G. R. Blake, A. Meetsma, A. Caretta, P. H. M. van Loosdrecht, T. T. M. Palstra, Chem. Mater., 24 (1) (2012) 133.

[2] A. Piecha-Bisiorek, A. Bieńko, R. Jakubas, R. Boča, M. Weselski, V. Kinzhybalo, A. Pietraszko, M. Wojciechowska, W. Medycki, D. Kruk, J. Phys. Chem. A, 120 (2016) 2014.

[3] B. Kundys, A. Lappas, M. Viret, V. Kapustianyk, V. Rudyk, S. Semak, C. Simon, I. Bakaimi, Phys. Rev. B, 81 (2010) 224434.

[4] (a) M. A. Asghar, S. Zhang, T. Khan, Z. Sun, A. Zeb, C. Ji, L. Li, S. Zhao, J. Luo, J. Mater. Chem. C, 4 (2016) 7537.

[5] (a) T. Khan, M. A. Asghar, Z. Sun, A. Zeb, C. Ji, J. Luo, J. Mater. Chem. C, 5 (2017) 2865; (b) A. Zeb, T. Khan, M. A. Asghar, Z. Sun, Z. Wu, S. Zhao, J. Luo, RSC Adv., 7 (2017) 24368.

[6] H.-Y. Ye, Q. Zhou, X. Niu, W.-Q. Liao, D.-W. Fu, Y. Zhang, Y.-M. You, J. Wang, Z.-N. Chen, R.-G. Xiong, J. Am. Chem. Soc., 137 (2015) 13148.

[7] W. Zhang, H.-Y. Ye, H.-L. Cai, J.-Z. Ge, R.-G. Xiong, S. D. Huang, J. Am. Chem. Soc., 132 (2010) 7300 .

[8] Y. Zhang, W. Qiang, L. D. W. Fu, H.Y. Ye, Z.N. Chen, R.G. Xiong, J. Am. Chem. Soc., 137 (2015) 4928.

[9] M. Liu, M. B. Johnsto, H. J. Snaith, Nature, 501 (2013) 395.

[10] (a) G. Xing, N. Mathews, S. S. Lim, N. Yantara, X. Liu, D. Sabba, M. Gratzel, S. Mhaisalkar, T. C. Sum, Nat. Mater., 13 (2014) 476; (b) H. Cho, S.-H. Jeong, M.-H. Park, Y.-H. Kim, C. Wolf, 
C.-L. Lee, J.-H. Heo, A. Sadhanala, N. Myoung, S. Yoo, S. H. Im, R. H. Friend, T.-W. Lee, Science, 350 (2015) 1222.

[11] (a) X.-H. Lv, W.-Q. Liao, P.-F. Li, Z.-X. Wang, C.-Y. Mao, Y. Zhang, J. Mater. Chem. C, 4 (2016) 1881; (b) W.-Q. Liao, H.- Y. Ye, Y. Zhang, R. G. Xiong, Dalton Trans., 44 (2015) 10614.

[12] J. Han, S. Nishihara, K. Inoue, M. Kurmoo, Inorg. Chem., 54 (2015) 2866.

[13] K. Hasebe, H. Mashiyama, S. Tanisaki, J. Phys. Soc. Japan, 49 (1980) 1633.

[14] H.-Y. Ye, D.-W. Fu, Y. Zhang, W. Zhang, R.-G. Xiong, S. D. Huang, J. Am. Chem. Soc., 131 (2009) 42.

[15] L. Z. Chen, Q. Ji, X. G. Wang, Q. J. Pan, X. X. Cao, CrystEngComm, 19 (2017) 5907.

[16] J. Harada, T. Shimojo, H. Oyamaguchi, H. Hasegawa, Y. Takahashi, K. Satomi, Y. Suzuki, J. Kawamata, T. Inabe, Nat. Chem. 8 (2016) 946.

[17] Y-Y. Tang, P-F. Li, P-P. Shi, W-Y. Zhang, Z-X. Wang, Y-M. You, H-Y. Ye, T. Nakamura, RG. Xiong, Phys. Rev. Lett., 119 (2017) 207602.

[18] H. L. Cai, W. Zhang, J. Z. Ge, Y. Zhang, K. Awaga, T. Nakamura, R. G. Xiong, Phys. Rev. Lett., 107 (2011) 147601.

[19] C-H. Chen, G.-C. Xu, CrystEngComm., 18 (2016) 550.

[20] Q. Ji, L. Li, S. Deng, X. Cao, L. Chen, Dalton Trans., 47 (2018) 5630.

[21] P.-F. Li, Y.-Y. Tang, Z.-X. Wang, H.-Y. Ye, Y.-M.You, R.-G. Xiong, Nat. Commun., 7 (2016) 13635.

[22] Y. Zhang, W. Zhang, S-H. Li, Q. Ye, H.-L. Cai, F. Deng, R-G. Xiong, S. D. Huang, J. Am. Chem. Soc., 134 (26) (2012) 11044.

[23] APEX2 program suite, 11-0, Bruker AXS Inc. Madison, Wisconsin, USA (2014).

[24] G.M. Sheldrick, SAINT, Version 8.37A, Bruker AXS Inc., Madison, Wisconsin, USA (2013).

[25] G.M. Sheldrick SADABS version, Bruker AXS Inc., Madison, Wisconsin, USA (2014).

[26] L. J. Farrugia. J. Appl. Cystallogr., 32 (1999) 837.

[27] A. Altomare, M. C. Burla, M. Camalli, G. L. Cascarano, C. Giacovazzo, A. Guagliardi, A. G. G. Moliterni, G. Polidori, R. J. Spagna, Appl. Crystallogr., 32 (2014) 115.

[28] G.M. Sheldrick. SHELXL-2014/1, Program for Crystal Structure Refinement University of Göttingen: Germany (2014).

[29] O.V. Dolomanov, L.J. Bourhis, R.J. Gildea, J.A.K. Howard, H. Puschmann, Olex2 program. J. Appl. Cryst., 42 (2009) 339.

[30] E. L. Muetterties, L. J. Guggenberger, J. Am. Chem. Soc., 96 (1974) 1748.

[31] A. Luque, J. Sertucha, L. Lezama, T. Rojo, P. Roman, J. Chem. Soc., 0 (1997) 847.

[32] I. B. H. Sadok, F. Hajlaoui, H. B. Ayed, N. Ennaceur, M. Nasri, N. Audebrand, T. Bataille, N. Zouari, J. Mol. Struct., 1167 (2018) 316. 
[33] K. Azouzi, B. Hamdi, R. Zouari, A. Ben Salah, Ionics, 22 (2016) 1669.

[34] D. Boenigk, D. J. Mootz, J. Am. Chem. Soc., 110 (1988) 2135.

[35] Y.-Y. Zheng, G. Wu, M. Deng, H.-Z. Chen, M. Wang, B.-Z. Tang, Thin Solid Films. 514 (2006) 127.

[36] A. A. Ballman, S. P. S. Porto, A. Yariv, J. Appl. Phys., 34 (1963) 3155.

[37] H. Kchaou, K. Karoui, K. Khirouni , A. Ben Rhaiem, J. Alloys Compd., 728 (2017) 936.

[38] J. L. Knutson, J. D. Martin, D. B. Mitzi, Inorg. Chem., 44 (2005) 4699.

[39] Q. Li, S. Li, K. Wang, Z. Quan, Y.Meng, B. Zou, J. Phys. Chem. Lett., 8 (2017) 500.

[40] H. Kchaou, A. Ben Rhaiem, K. Karoui, F. jomni, K. Guidara, Appl. Phys. A. 122 (2016) 82.

[41] A. El-Korashy, H. El-Zahed, M. Radwan, Physica B. Condens. Matter. 334 (2003) 75.

[42] M.D. Migahed, N.A. Bakr, M.I. Abdel-Hamid, O. EL-Hannafy, M. El-Nimr, J. Appl. Polym. Sci., 59 (1996) 655.

[43] G.C. Psarras, E. Manolakaki, G.M. Tsangaris, Composites: Part A. 34 (2003) 1187.

[44] R. Murugaraj, G. Govindaraj, D. George, Mater. Lett., 57 (2003) 1656.

[45] R.M. Hill, A.K. Jonscher, J. Non-Cryst. Solids. 32 (1979) 53.

[46] R.H. Chen, R.Y. Chang, S.C. Shern, J. Phys. Chem. Solids. 63 (2002) 2069.

[47] H. Nefzi, F. Sediri, H. Hamzaoui, N. Gharbi, Mater. Res. Bull., 48 (2013) 1978.

[48] C. Ben Mohamed, K. Karoui, S. Saidi, K. Guidara, A. Ben Rhaiem, Physica B. 451 (2014) 87.

[49] A. Ghosh, Phys. Rev., B42 (1990) 5665.

[50] M. Ben Bechir, K. Karoui, M. Tabellout, K. Guidara, A. Ben Rhaiem, J. Appl. Phys., 115 (2014) 15370.

\section{Figure captions}

Figure 1: The asymmetric unit of $\left[\mathrm{C}_{7} \mathrm{H}_{16} \mathrm{~N}_{2}\right]\left[\mathrm{CuCl}_{4}\right]$ showing the atom-numbering scheme involving $\mathrm{N}-\mathrm{H} \cdots \mathrm{Cl}$ hydrogen bonding.

Figure 2: View of $\left[\mathrm{C}_{7} \mathrm{H}_{16} \mathrm{~N}_{2}\right]\left[\mathrm{CuCl}_{4}\right]$ along the $b$-axis. The dotted lines indicate hydrogen bonds.

Figure 3: Experimental Raman and IR spectra of the $\left[\mathrm{C}_{7} \mathrm{H}_{16} \mathrm{~N}_{2}\right]\left[\mathrm{CuCl}_{4}\right]$ compound.

Figure 4: Optical absorption spectrum of $\left[\mathrm{C}_{7} \mathrm{H}_{16} \mathrm{~N}_{2}\right]\left[\mathrm{CuCl}_{4}\right]$ compound at room temperature.

Figure 5: Determination of Gap energy of $\left[\mathrm{C}_{7} \mathrm{H}_{16} \mathrm{~N}_{2}\right]\left[\mathrm{CuCl}_{4}\right]$ compound.

Figure 6: $\mathrm{TG}$ curve for the decomposition of $\left[\mathrm{C}_{7} \mathrm{H}_{16} \mathrm{~N}_{2}\right]\left[\mathrm{CuCl}_{4}\right]$, under flowing nitrogen $\left(5^{\circ} \mathrm{C} / \mathrm{min}\right.$ from 298 to $873 \mathrm{~K})$.

Figure 7: Differential scanning calorimetric of the $\left[\mathrm{C}_{7} \mathrm{H}_{16} \mathrm{~N}_{2}\right]\left[\mathrm{CuCl}_{4}\right]$.

Figure 8 (a), (b), (c) and (d): Nyquist diagram spectra at several temperature of $\left[\mathrm{C}_{7} \mathrm{H}_{16} \mathrm{~N}_{2}\right]\left[\mathrm{CuCl}_{4}\right]$. 
Figure 9 (a) and (b): Theoretical and experimental curves of Z' and Z" as a function of frequency and Nyquist diagram of $\left[\mathrm{C}_{7} \mathrm{H}_{16} \mathrm{~N}_{2}\right]\left[\mathrm{CuCl}_{4}\right]$.

Figure 10: Variation of the $\ln \left(\sigma_{\mathrm{g}}\right)$ versus $1000 / \mathrm{T}$ of $\left[\mathrm{C}_{7} \mathrm{H}_{16} \mathrm{~N}_{2}\right]\left[\mathrm{CuCl}_{4}\right]$.

Figure 11 (a) and (b): Angular frequency dependence of the imaginary part of electric modulus at several temperatures of $\left[\mathrm{C}_{7} \mathrm{H}_{16} \mathrm{~N}_{2}\right]\left[\mathrm{CuCl}_{4}\right]$.

Figure 12: Temperature dependence of the relaxation frequency of $\left[\mathrm{C}_{7} \mathrm{H}_{16} \mathrm{~N}_{2}\right]\left[\mathrm{CuCl}_{4}\right]$.

Figure 13: Frequency dependence of the AC conductivity at various temperatures of $\left[\mathrm{C}_{7} \mathrm{H}_{16} \mathrm{~N}_{2}\right]\left[\mathrm{CuCl}_{4}\right]$.

Figure 14: Variation of the $\ln \left(\sigma_{\mathrm{dc}}\right)$ versus $1000 / \mathrm{T}$ of $\left[\mathrm{C}_{7} \mathrm{H}_{16} \mathrm{~N}_{2}\right]\left[\mathrm{CuCl}_{4}\right]$.

Figure 15: Temperature dependence of the exponent $\mathrm{S}$ of $\left[\mathrm{C}_{7} \mathrm{H}_{16} \mathrm{~N}_{2}\right]\left[\mathrm{CuCl}_{4}\right]$.

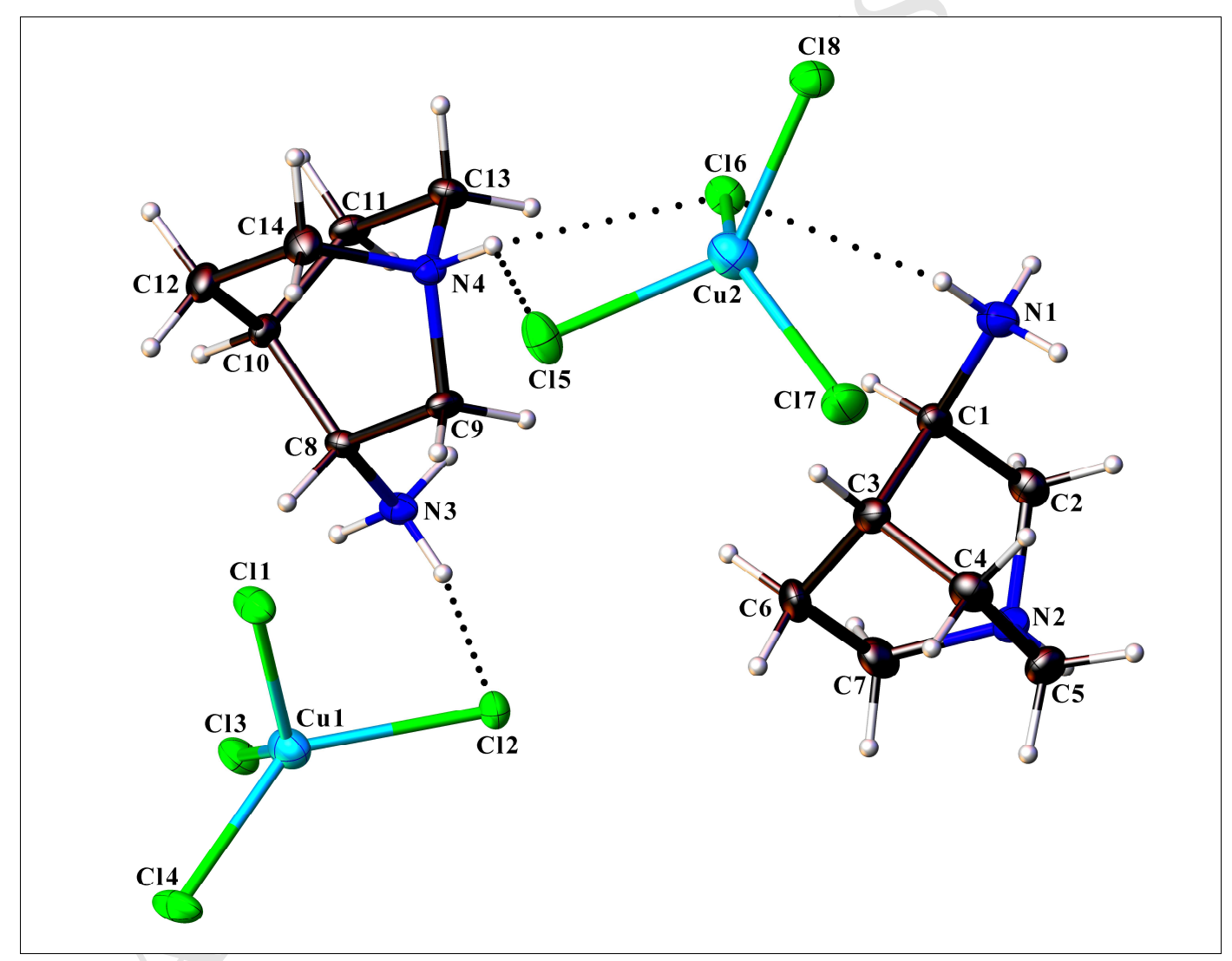

Figure 1: The asymmetric unit of $\left[\mathrm{C}_{7} \mathrm{H}_{16} \mathrm{~N}_{2}\right]\left[\mathrm{CuCl}_{4}\right]$ showing the atom-numbering scheme involving $\mathrm{N}-\mathrm{H} \cdots \mathrm{Cl}$ hydrogen bonding. 


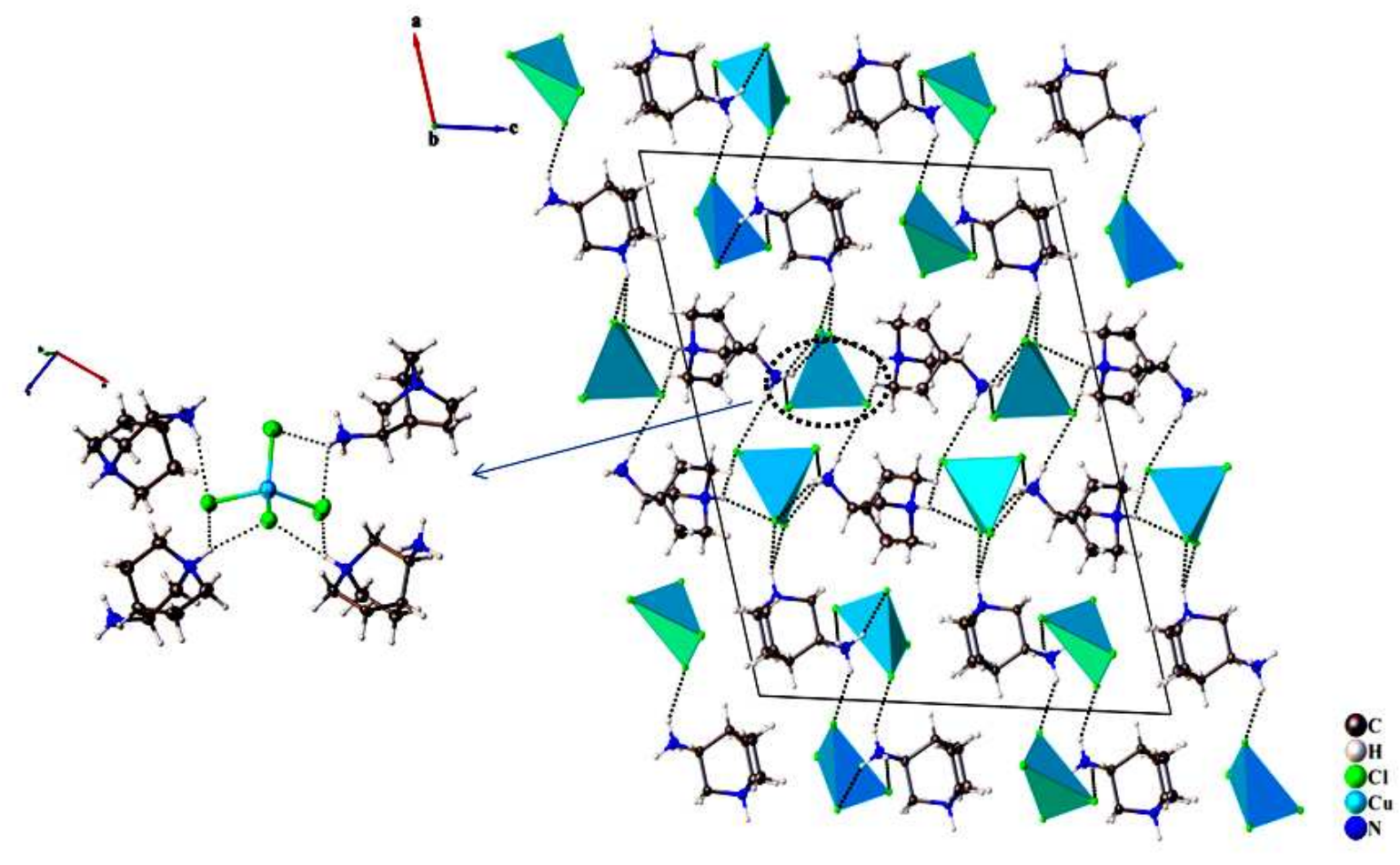

Figure 2: View of $\left[\mathrm{C}_{7} \mathrm{H}_{16} \mathrm{~N}_{2}\right]\left[\mathrm{CuCl}_{4}\right]$ along the $b$-axis. The dotted lines indicate hydrogen bonds. 


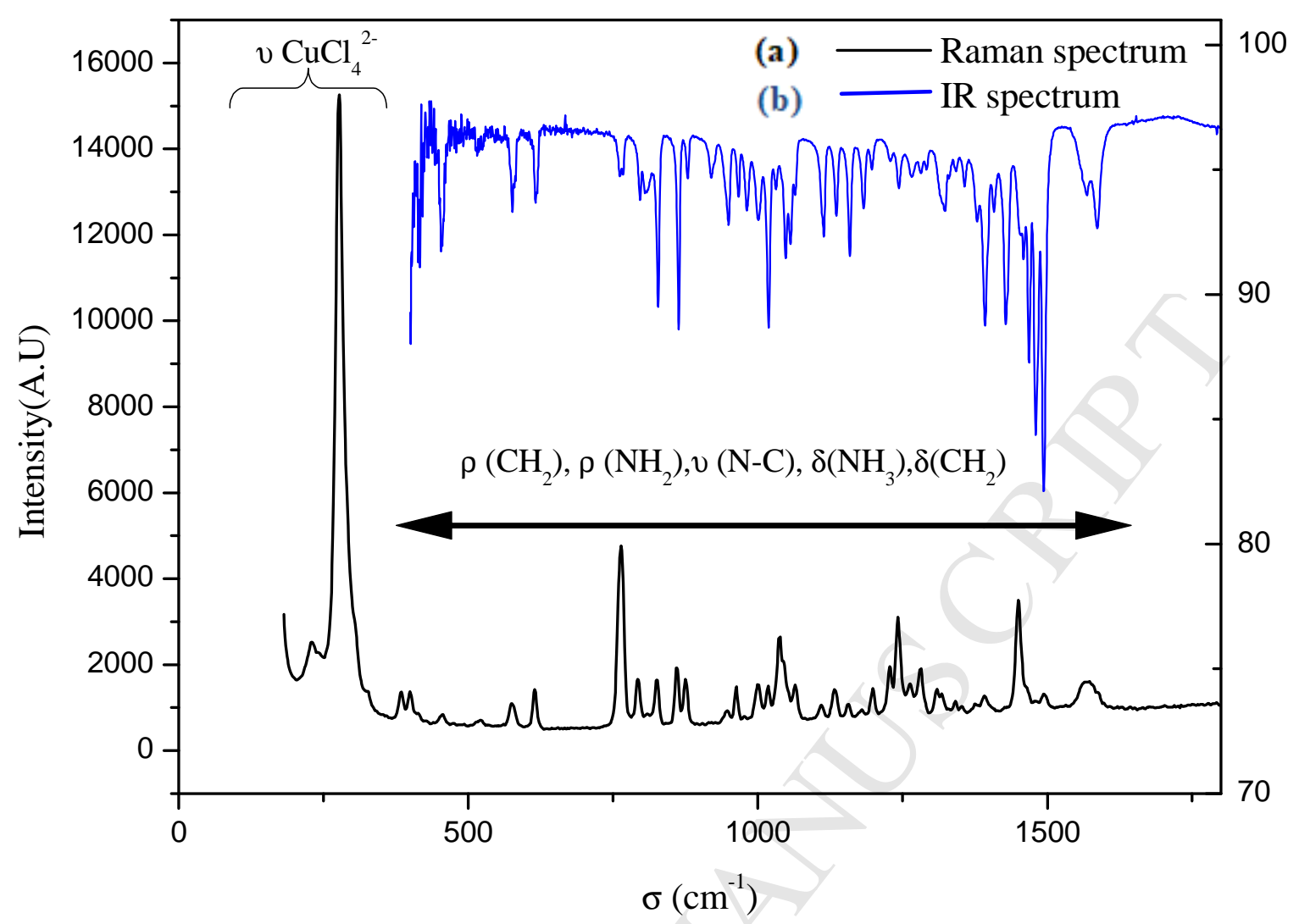

Figure 3 (a) and (b): Experimental Raman and IR spectra of the $\left[\mathrm{C}_{7} \mathrm{H}_{16} \mathrm{~N}_{2}\right]\left[\mathrm{CuCl}_{4}\right]$.

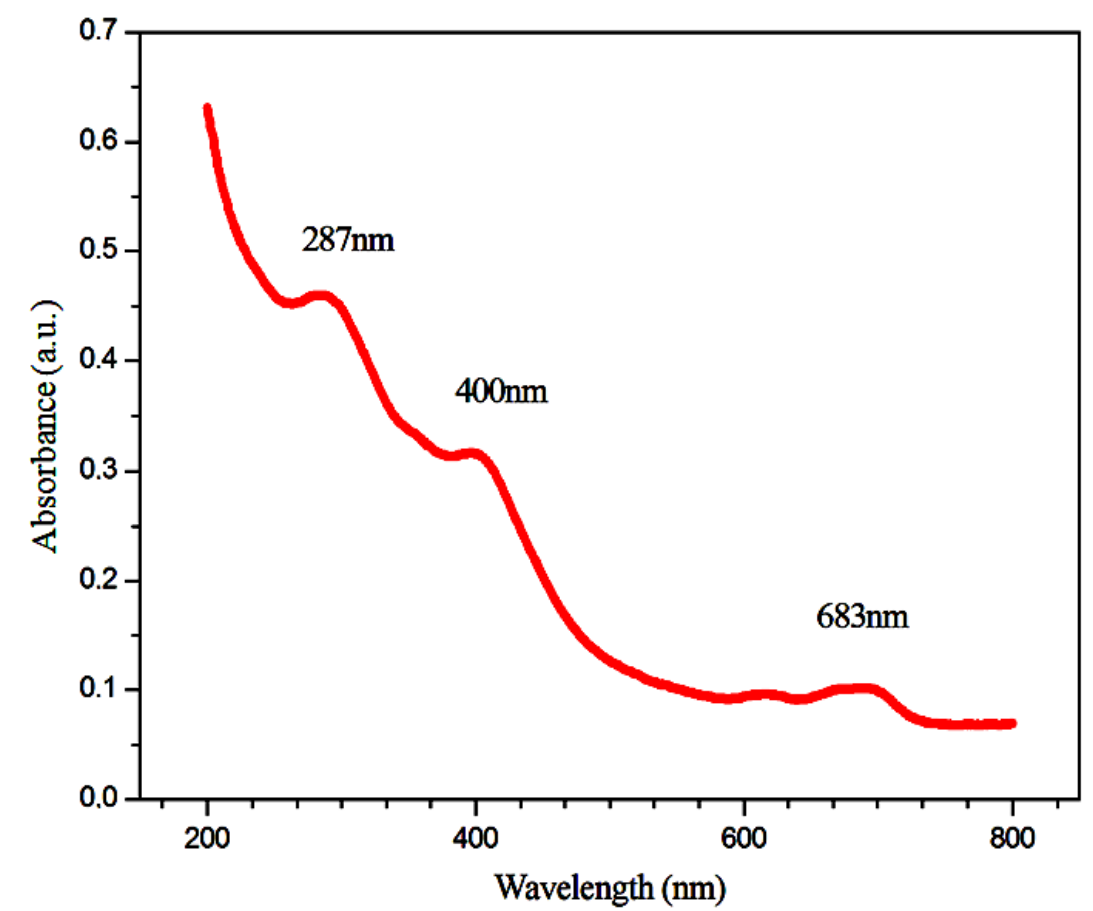

Figure 4: Optical absorption spectrum of $\left[\mathrm{C}_{7} \mathrm{H}_{16} \mathrm{~N}_{2}\right]\left[\mathrm{CuCl}_{4}\right]$ at room temperature. 


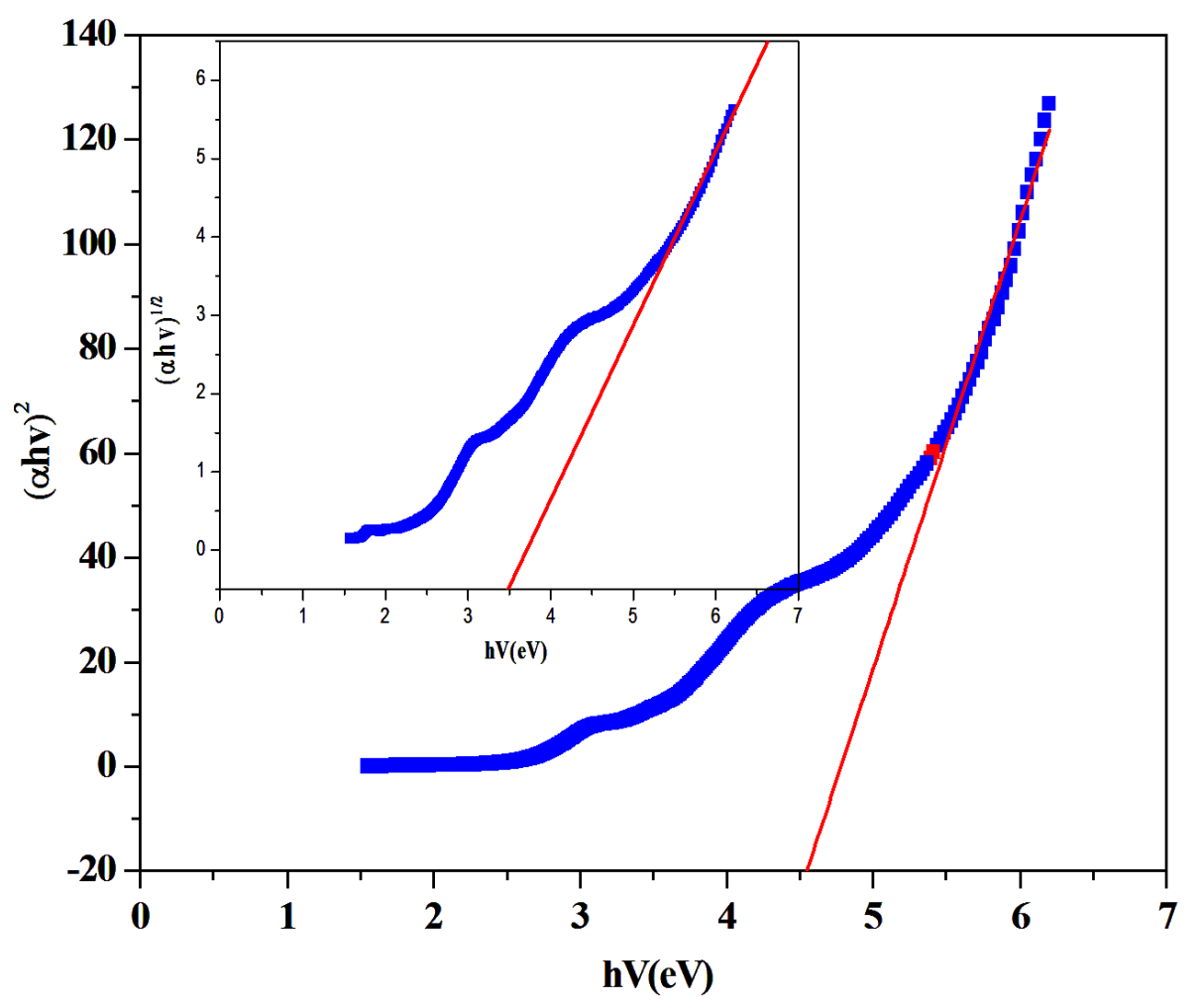

Figure 5: Determination of Gap energy of $\left[\mathrm{C}_{7} \mathrm{H}_{16} \mathrm{~N}_{2}\right]\left[\mathrm{CuCl}_{4}\right]$.

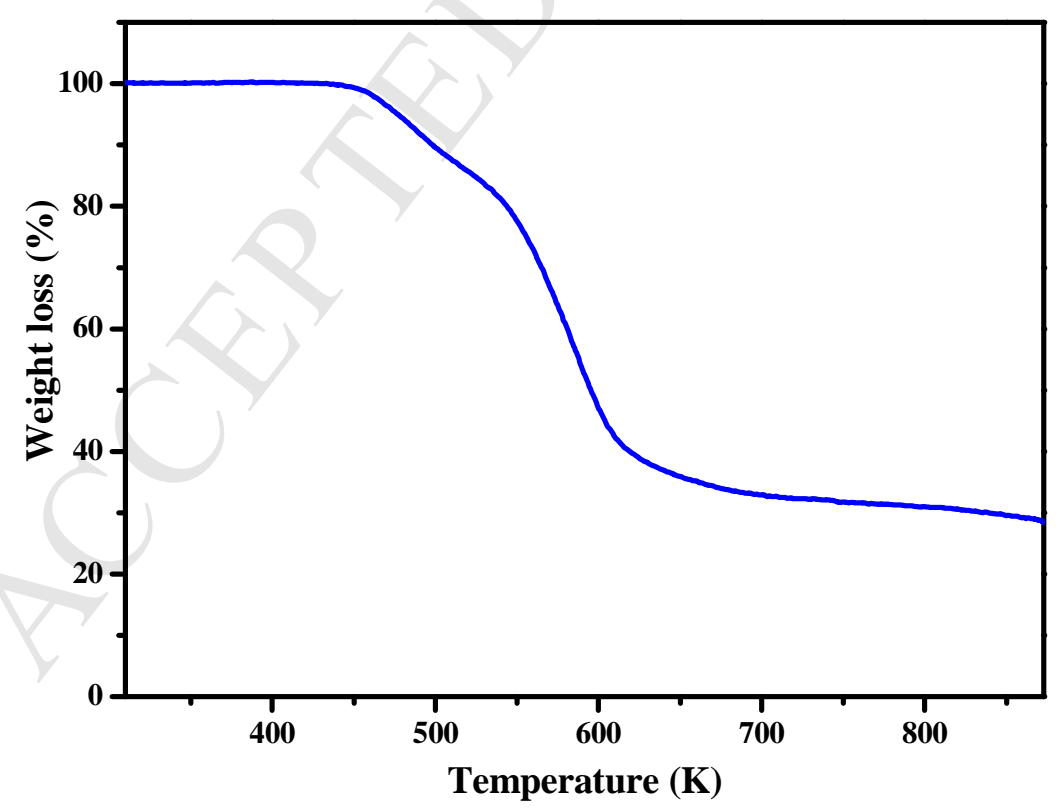

Figure 6: TG curve for the decomposition of $\left[\mathrm{C}_{7} \mathrm{H}_{16} \mathrm{~N}_{2}\right]\left[\mathrm{CuCl}_{4}\right]$, under flowing nitrogen $\left(5^{\circ} \mathrm{C} / \mathrm{min}\right.$ from 298 to $\left.873 \mathrm{~K}\right)$. 


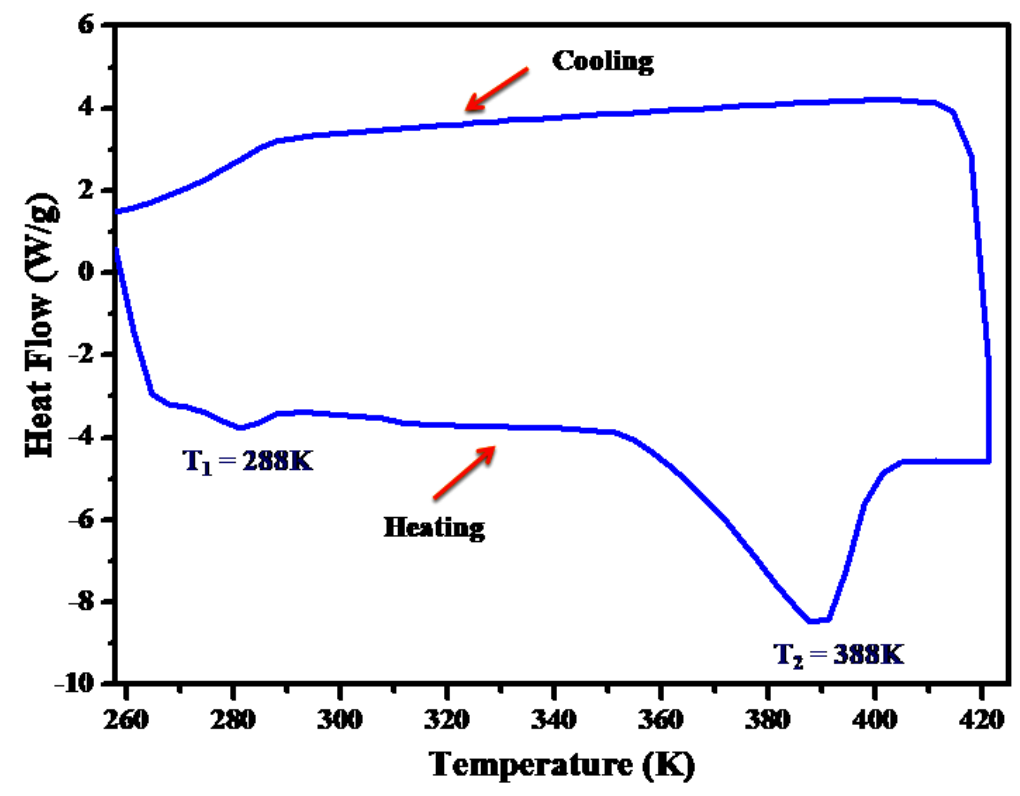

Figure 7: Differential scanning calorimetric of the $\left[\mathrm{C}_{7} \mathrm{H}_{16} \mathrm{~N}_{2}\right]\left[\mathrm{CuCl}_{4}\right]$.
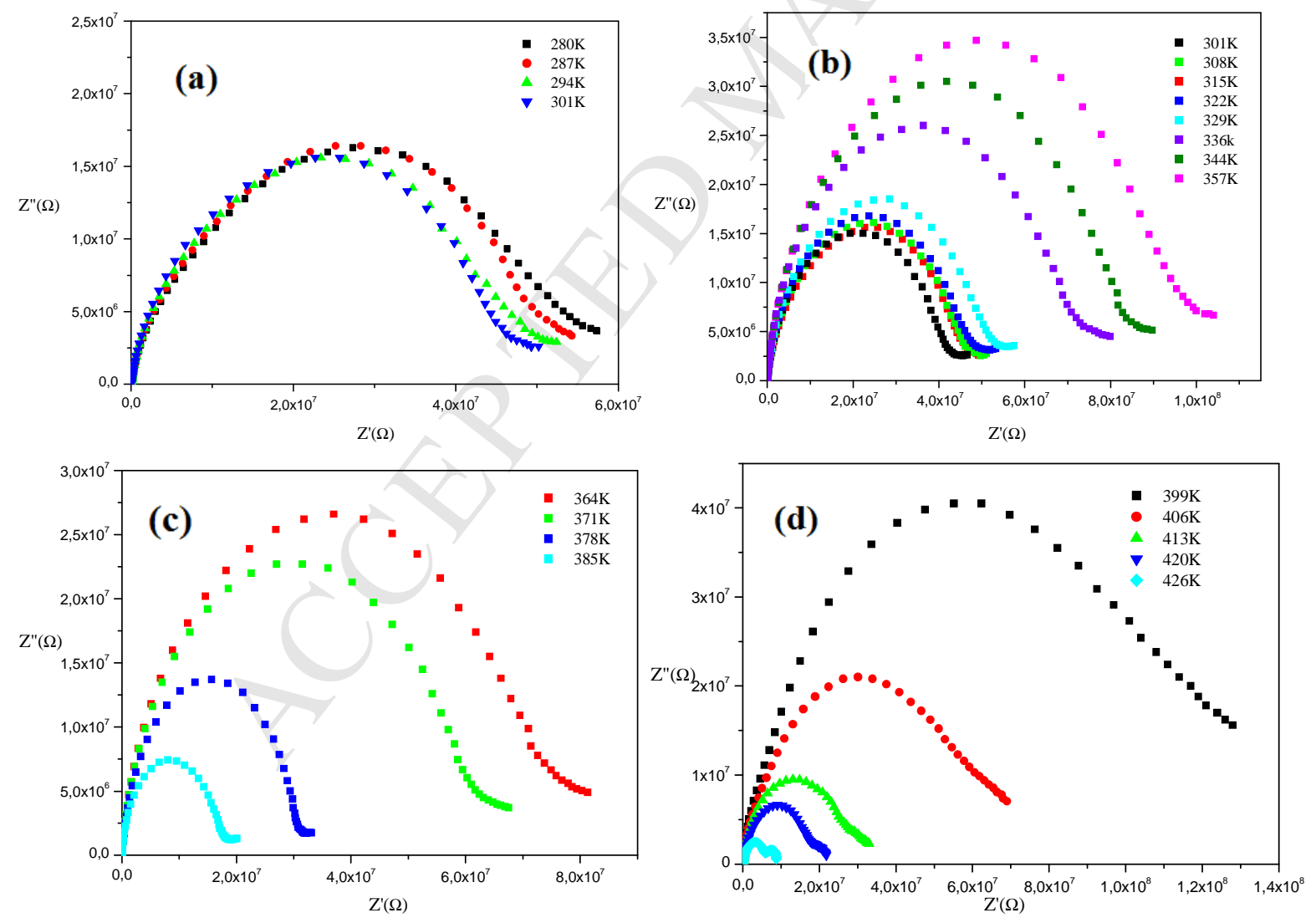

Figure 8 (a), (b), (c) and (d): Nyquist diagram spectra at several temperature of $\left[\mathrm{C}_{7} \mathrm{H}_{16} \mathrm{~N}_{2}\right]\left[\mathrm{CuCl}_{4}\right]$. 

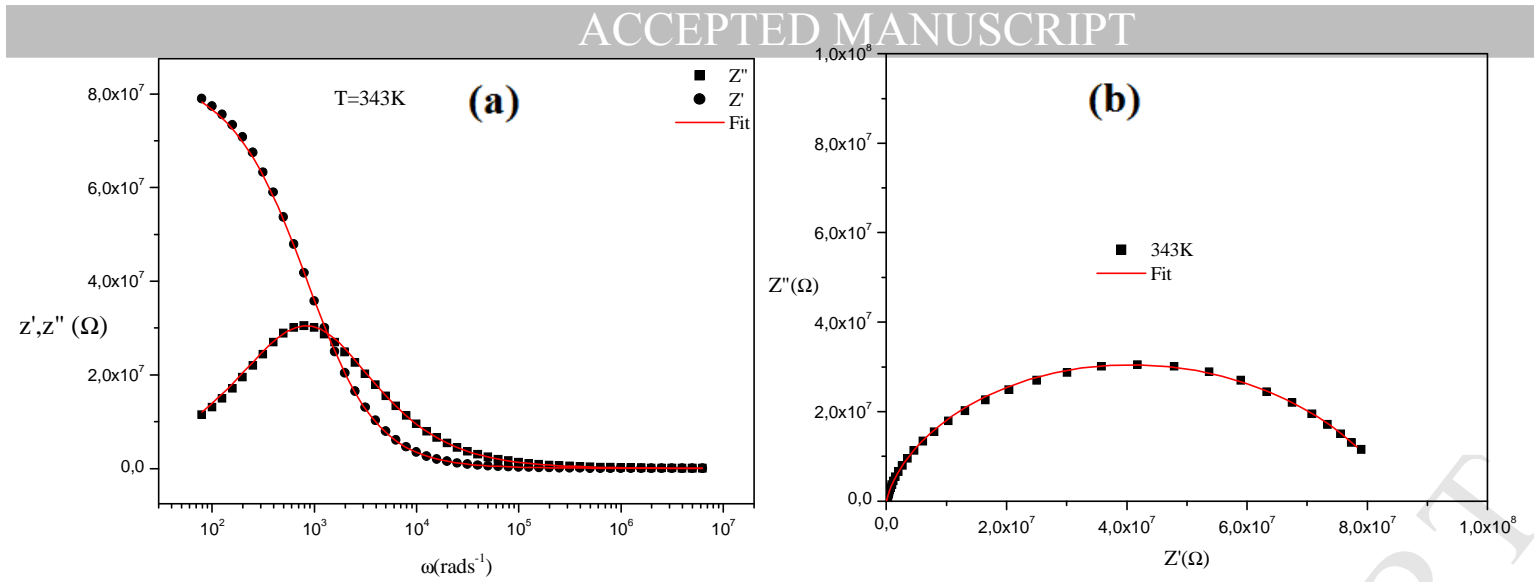

Figure 9 (a) and (b): Theoretical and experimental curves of Z' and Z"' as a function of frequency and Nyquist diagram of $\left[\mathrm{C}_{7} \mathrm{H}_{16} \mathrm{~N}_{2}\right]\left[\mathrm{CuCl}_{4}\right]$.

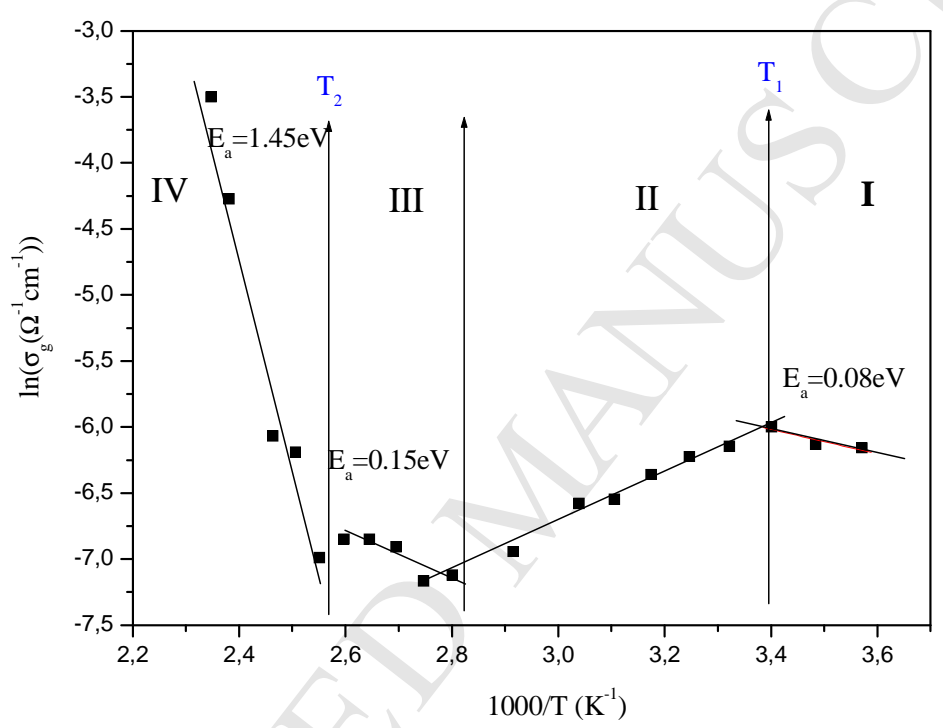

Figure 10: Variation of the $\ln \left(\sigma_{\mathrm{g}}\right)$ versus $1000 / \mathrm{T}$ of $\left[\mathrm{C}_{7} \mathrm{H}_{16} \mathrm{~N}_{2}\right]\left[\mathrm{CuCl}_{4}\right]$.
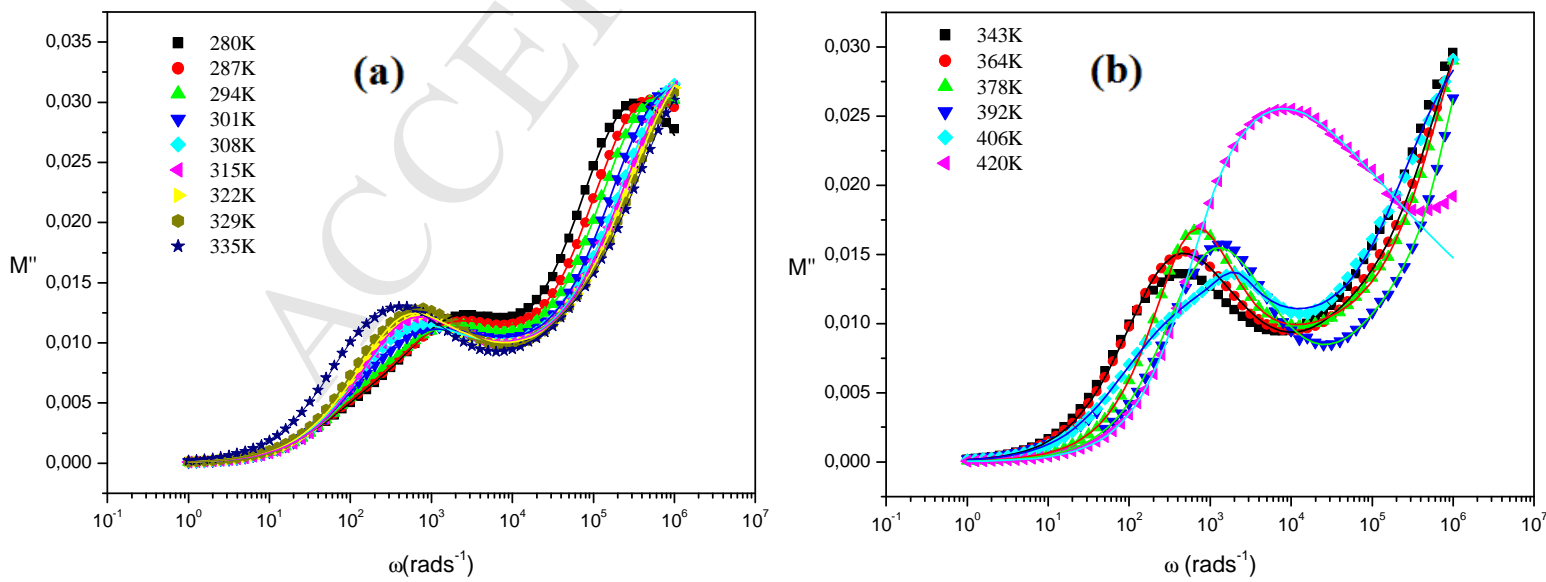

Figure 11 (a) and (b): Angular frequency dependence of the imaginary part of electric modulus at several temperatures of $\left[\mathrm{C}_{7} \mathrm{H}_{16} \mathrm{~N}_{2}\right]\left[\mathrm{CuCl}_{4}\right]$. 


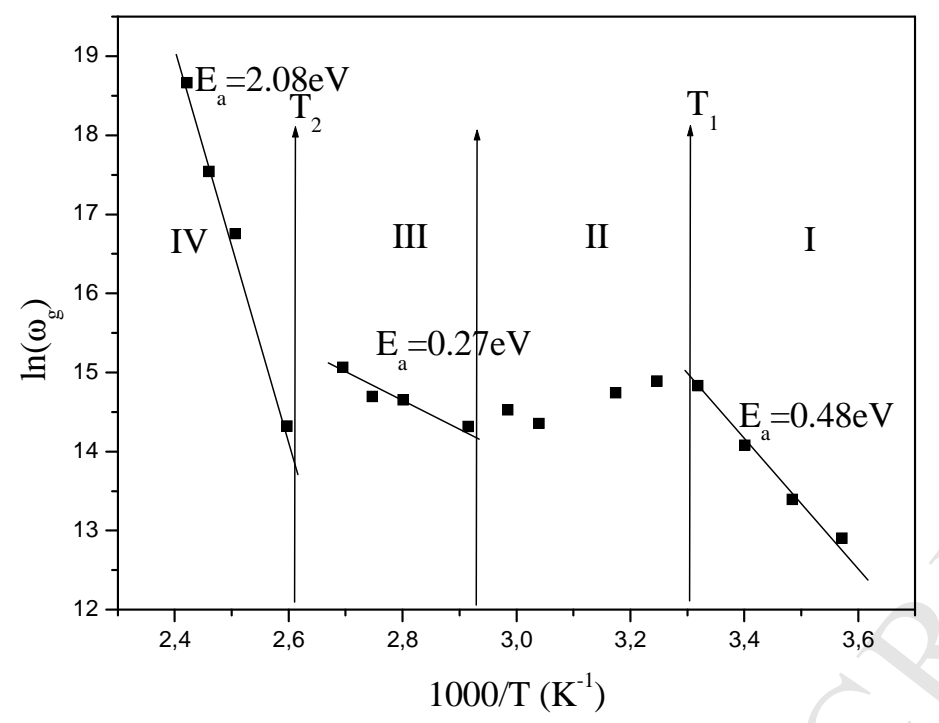

Figure 12: Temperature dependence of the relaxation frequency of $\left[\mathrm{C}_{7} \mathrm{H}_{16} \mathrm{~N}_{2}\right]\left[\mathrm{CuCl}_{4}\right]$.

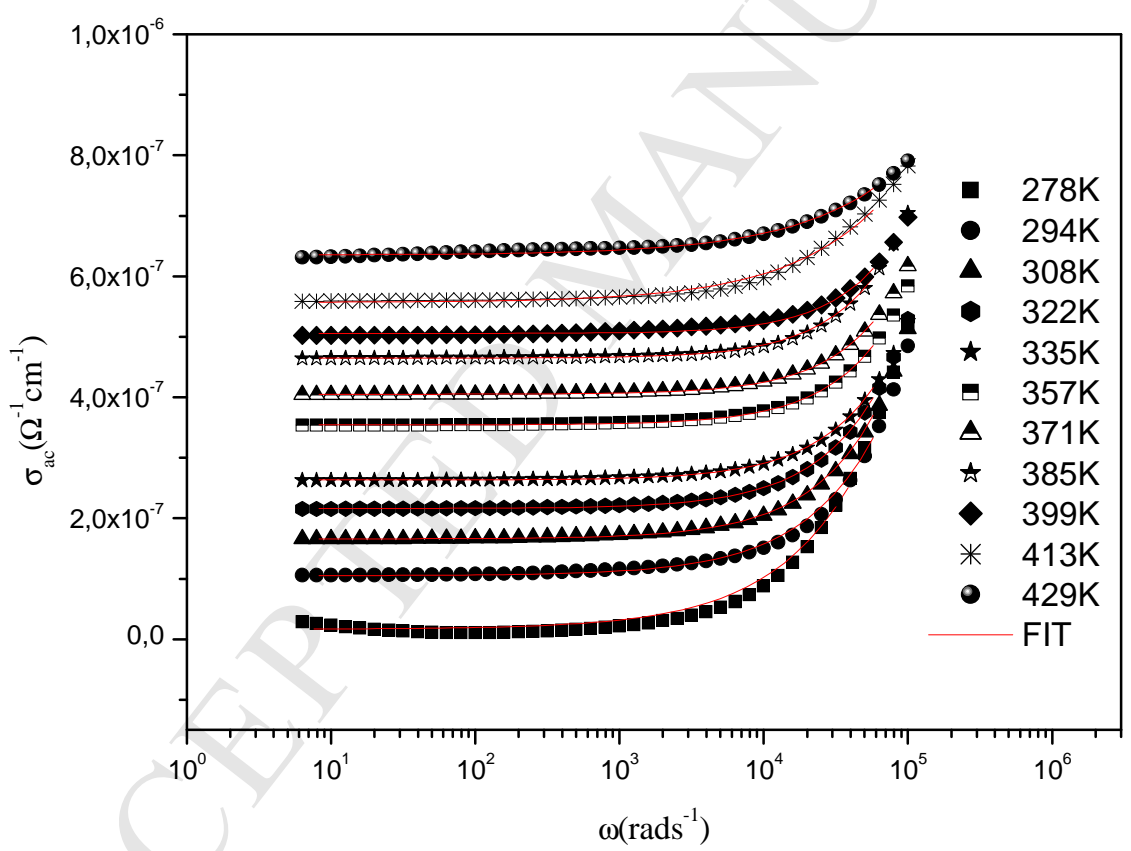

Figure 13: Frequency dependence of the $\mathrm{AC}$ conductivity at various temperatures of $\left[\mathrm{C}_{7} \mathrm{H}_{16} \mathrm{~N}_{2}\right]\left[\mathrm{CuCl}_{4}\right]$. 


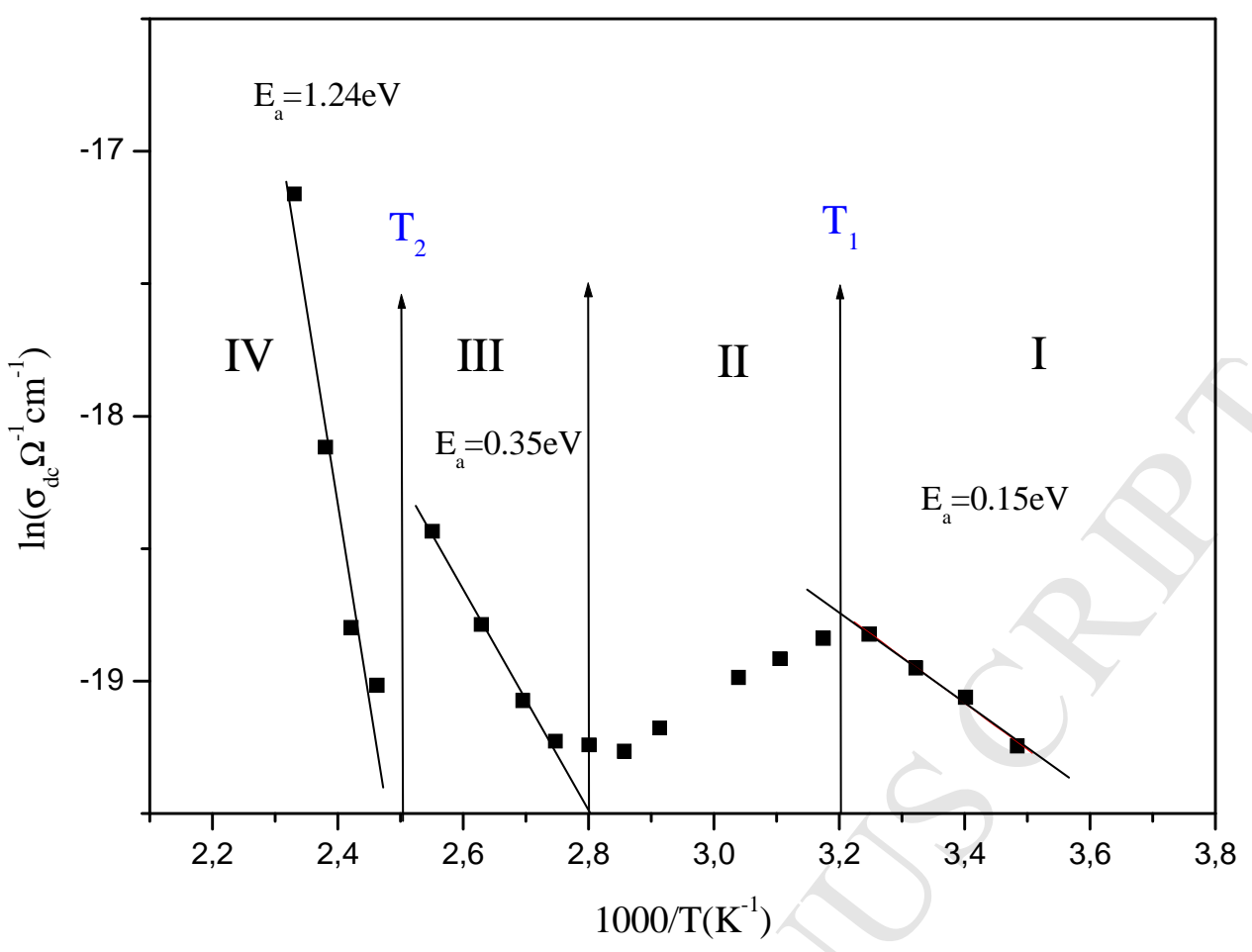

Figure 14: Variation of the $\ln \left(\sigma_{\mathrm{dc}}\right)$ versus $1000 / \mathrm{T}$ of $\left[\mathrm{C}_{7} \mathrm{H}_{16} \mathrm{~N}_{2}\right]\left[\mathrm{CuCl}_{4}\right]$.

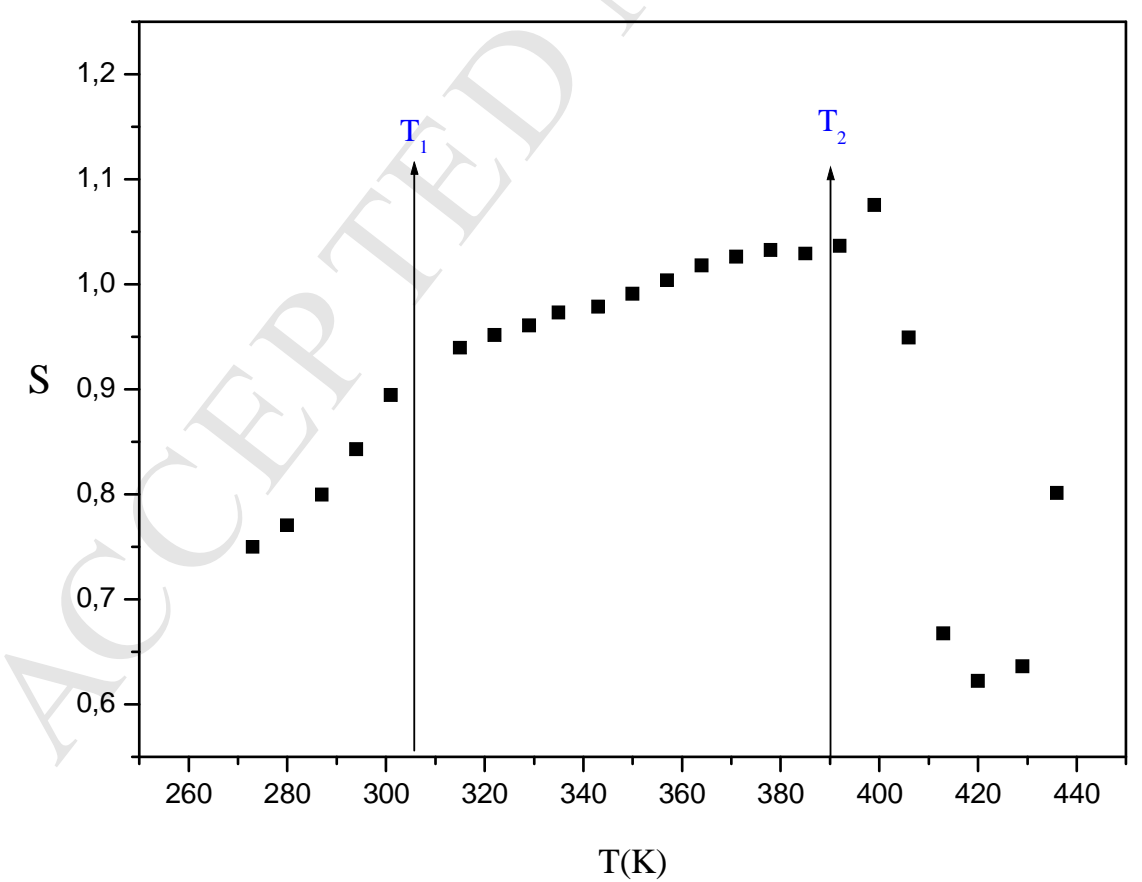

Figure 15: Temperature dependence of the exponent $\mathrm{S}$ of $\left[\mathrm{C}_{7} \mathrm{H}_{16} \mathrm{~N}_{2}\right]\left[\mathrm{CuCl}_{4}\right]$. 


\section{Table captions}

Table 1: Crystallographic data and structure refinement parameters for $\left[\mathrm{C}_{7} \mathrm{H}_{16} \mathrm{~N}_{2}\right]\left[\mathrm{CuCl}_{4}\right]$.

Table 2: Selected bond distances $(\AA)$ and angles $\left(^{\circ}\right)$ in $\left[\mathrm{C}_{7} \mathrm{H}_{16} \mathrm{~N}_{2}\right]\left[\mathrm{CuCl}_{4}\right]$.

Table 3: Hydrogen-bonding geometry $\left(\AA{ }^{\circ}{ }^{\circ}\right)$ for $\left[\mathrm{C}_{7} \mathrm{H}_{16} \mathrm{~N}_{2}\right]\left[\mathrm{CuCl}_{4}\right]$.

Table 1: Crystallographic data and structure refinement parameters for $\left[\mathrm{C}_{7} \mathrm{H}_{16} \mathrm{~N}_{2}\right]\left[\mathrm{CuCl}_{4}\right]$.

\begin{tabular}{|c|c|}
\hline Empirical formula & $\mathrm{C}_{7} \mathrm{H}_{16} \mathrm{~N}_{2} \mathrm{Cl}_{4} \mathrm{Cu}$ \\
\hline Formula weight $\left(\mathrm{g} \cdot \mathrm{mol}^{-1}\right)$ & 333.57 \\
\hline Temperature $(\mathrm{K})$ & 296 \\
\hline Crystal system & Monoclinic \\
\hline Space group & $P 2_{1} / c$ \\
\hline$a(\AA)$ & $21.4852(1)$ \\
\hline$b(\AA)$ & $7.3367(3)$ \\
\hline$c(\AA)$ & $17.1508(8)$ \\
\hline$\alpha\left(^{\circ}\right)$ & 90 \\
\hline$\beta\left(^{\circ}\right)$ & $105.865(2)$ \\
\hline$\gamma\left({ }^{\circ}\right)$ & 90 \\
\hline$V\left(\AA^{3}\right)$ & $2600.5(2)$ \\
\hline $\mathrm{Z}$ & 4 \\
\hline$\lambda(\operatorname{MoK} \alpha)(\AA)$ & 0.71073 \\
\hline$\rho \mathrm{cal}\left(\mathrm{g} \cdot \mathrm{cm}^{-1}\right)$ & 1.704 \\
\hline Absorption correction & Multi-scan \\
\hline$\mu\left(\mathrm{mm}^{-1}\right)$ & 2.468 \\
\hline Crystal size $\left(\mathrm{mm}^{3}\right)$ & $0.59 \times 0.21 \times 0.17$ \\
\hline Crystal color/shape & Stick orange \\
\hline$h k l$ range & $-27 \leq \mathrm{h} \leq 24 ;-9 \leq \mathrm{k} \leq 9 ;-16 \leq 1 \leq 22$ \\
\hline$\theta$ range for data collection (deg) & $0.994-27.506$ \\
\hline Refinement method & Full-matrix least-squares on $\mathrm{F}^{2}$ \\
\hline No. of collected reflections & 18210 \\
\hline No. of independent reflections & 5949 \\
\hline Observed reflections / restrains / parameters & $4454 / 0 / 253$ \\
\hline$R_{\text {int }}$ & 0.0378 \\
\hline $\mathrm{F}(000)$ & 1352 \\
\hline Goodness of fit & 1.030 \\
\hline Transmission factors & $\mathrm{T}_{\min }=0.542, \mathrm{~T}_{\max }=0.657$ \\
\hline $\mathrm{R}$ indices & $\mathrm{R}_{1}=0.0377, \mathrm{wR}_{2}=0.0906$ \\
\hline Largest difference map hole $\left(\mathrm{e} \AA^{-3}\right)$ & $\Delta \rho_{\max }=0.74, \Delta \rho_{\min }=-0.68$ \\
\hline
\end{tabular}


Table 2: Selected bond distances $(\AA)$ and angles $\left(^{\circ}\right)$ for $\left[\mathrm{C}_{7} \mathrm{H}_{16} \mathrm{~N}_{2}\right]\left[\mathrm{CuCl}_{4}\right]$.

\begin{tabular}{llll}
\hline $\mathrm{Cu} 1-\mathrm{Cl} 1$ & $2.2709(9)$ & $\mathrm{Cu} 2-\mathrm{Cl} 5$ & $2.2307(9)$ \\
$\mathrm{Cu} 1-\mathrm{Cl} 2$ & $2.2529(8)$ & $\mathrm{Cu} 2-\mathrm{Cl} 6$ & $2.2653(9)$ \\
$\mathrm{Cu} 1-\mathrm{Cl} 3$ & $2.2553(9)$ & $\mathrm{Cu} 2-\mathrm{Cl} 7$ & $2.2213(10)$ \\
$\mathrm{Cu} 1-\mathrm{Cl} 4$ & $2.2122(9)$ & $\mathrm{Cu} 2-\mathrm{Cl} 8$ & $2.2462(9)$ \\
$\mathrm{Cl} 4-\mathrm{Cu} 1-\mathrm{Cl} 2$ & $135.39(4)$ & $\mathrm{Cl}-\mathrm{Cu} 2-\mathrm{Cl} 5$ & $99.83(4)$ \\
$\mathrm{Cl} 4-\mathrm{Cu} 1-\mathrm{Cl} 3$ & $100.07(4)$ & $\mathrm{Cl}-\mathrm{Cu} 2-\mathrm{Cl} 8$ & $103.36(4)$ \\
$\mathrm{Cl} 2-\mathrm{Cu} 1-\mathrm{Cl} 3$ & $96.58(3)$ & $\mathrm{Cl} 5-\mathrm{Cu} 2-\mathrm{Cl} 8$ & $130.15(4)$ \\
$\mathrm{Cl} 4-\mathrm{Cu} 1-\mathrm{Cl} 1$ & $100.64(3)$ & $\mathrm{Cl} 1-\mathrm{Cu} 2-\mathrm{Cl} 6$ & $130.34(4)$ \\
$\mathrm{Cl} 2-\mathrm{Cu} 1-\mathrm{Cl} 1$ & $97.44(3)$ & $\mathrm{Cl} 5-\mathrm{Cu} 2-\mathrm{Cl} 6$ & $99.44(3)$ \\
$\mathrm{Cl} 3-\mathrm{Cu} 1-\mathrm{Cl} 1$ & $132.98(4)$ & $\mathrm{Cl}-\mathrm{Cu} 2-\mathrm{Cl} 6$ & $98.07(3)$ \\
$\Delta D(\%)=26.8$ & & $\Delta D(\%)=27.5$ & \\
& & & \\
\hline
\end{tabular}

$\Delta D(\%)$ : Muetterties distortion from the tetrahedron

$\Delta D(\%)$ was calculated according to: $\Delta \boldsymbol{D}(\boldsymbol{\%})=(\mathbf{1} / \mathbf{n}) \Sigma_{\mathbf{j}}\left(\left|\Sigma_{\mathbf{i}}\left(\boldsymbol{\delta}_{\mathbf{i}}-\boldsymbol{\delta}_{\mathbf{j} 1}\right)\right| / /\left(\boldsymbol{\delta}_{\mathbf{j} 1^{-}} \boldsymbol{\delta}_{\mathbf{j} 2}\right) \mid \times \mathbf{1 0 0}\right.$, where $\delta_{\mathrm{i}}$ is the experimental dihedral angle and $\delta_{\mathrm{j} 1}$ and $\delta_{\mathrm{j} 2}$ are the theoretical dihedral angles for $T_{d}$ and $D_{4 h}$, respectively, and $\mathrm{n}=1-6$ are the six bond angles around the metal.

Table 3: Hydrogen-bonding geometry $\left(\AA,^{\circ}\right)$ for $\left[\mathrm{C}_{7} \mathrm{H}_{16} \mathrm{~N}_{2}\right]\left[\mathrm{CuCl}_{4}\right]$.

\begin{tabular}{lllll}
\hline $\mathbf{D}-\mathbf{H} \cdots \mathbf{A}$ & $\mathbf{D}-\mathbf{H}$ & $\mathbf{H} \cdots \mathbf{A}$ & $\mathbf{D} \cdots \mathbf{A}$ & $\mathbf{D}-\mathbf{H} \cdots \mathbf{A}$ \\
\hline $\mathrm{N} 1-\mathrm{H} 1 \mathrm{~A} \cdots \mathrm{Cl} 6$ & 0.89 & 2.53 & $3.329(3)$ & 150 \\
$\mathrm{~N} 1-\mathrm{H} 1 \mathrm{~B} \cdots \mathrm{Cl} 5^{(\mathrm{i})}$ & 0.89 & 2.57 & $3.249(3)$ & 133 \\
$\mathrm{~N} 1-\mathrm{H} 1 \mathrm{~B} \cdots \mathrm{Cl} 7^{(\mathrm{i})}$ & 0.89 & 2.59 & $3.352(3)$ & 144 \\
$\mathrm{~N} 1-\mathrm{H} 1 \mathrm{C} \cdots \mathrm{Cl}{ }^{(\mathrm{ii})}$ & 0.89 & 2.51 & $3.345(3)$ & 157 \\
$\mathrm{~N} 2-\mathrm{H} 2 \cdots \mathrm{Cl} 6^{(\mathrm{iii})}$ & 0.91 & 2.49 & $3.278(3)$ & 145 \\
$\mathrm{~N} 2-\mathrm{H} 2 \cdots \mathrm{Cl} 8^{(\mathrm{iii})}$ & 0.91 & 2.68 & $3.347(3)$ & 131 \\
$\mathrm{~N} 4-\mathrm{H} 4 \cdots \mathrm{Cl} 6$ & 0.91 & 2.60 & $3.324(3)$ & 137 \\
$\mathrm{~N} 4-\mathrm{H} 4 \cdots \mathrm{Cl} 5$ & 0.91 & 2.61 & $3.283(3)$ & 131 \\
$\mathrm{~N} 3-\mathrm{H} 3 \mathrm{~A} \cdots \mathrm{Cl} 2$ & 0.89 & 2.70 & $3.448(3)$ & 142 \\
$\mathrm{~N} 3-\mathrm{H} 3 \mathrm{~B} \cdots \mathrm{Cl} 1^{(\mathrm{i})}$ & 0.89 & 2.41 & $3.230(3)$ & 153 \\
$\mathrm{~N} 3-\mathrm{H} 3 \mathrm{C} \cdots \mathrm{Cl} 3^{(\mathrm{iv})}$ & 0.89 & 2.57 & $3.226(3)$ & 131 \\
\hline
\end{tabular}

Symmetry codes : ${ }^{\text {(i) }} \mathrm{x}, \mathrm{y}-1, z$; $^{\text {(ii) }}-x+1, y-1 / 2,-z-1 / 2 ;{ }^{\text {(iii) }} x,-y+3 / 2, z+1 / 2 ;{ }^{\text {(iv) }}-x, y-1 / 2,-z-1 / 2$. 


\section{Highlights}

- $\quad$ Novel organic-inorganic Copper (II) Halide was prepared and characterized by different techniques.

- $\quad$ Single-crystal X-ray studies confirmed the H-bonded network

- $\quad$ Optical study was investigated by the methods of UV-Vis absorption

- Differential scanning calorimetric shows several phase transitions.

- $\quad$ Electrical conductivity confirms the phase transitions detected well with DSC analysis. 